\title{
Developing stem cells - the hard way
}

I $\mathrm{n}$ a development that epitomizes the often roundabout path of progress in molecular biology, American researchers have employed a largely abandoned method — one that would be illegal in Canada - to turn human skin cells into embryonic stem cells.

That method is somatic cell nuclear transfer, the basis of cloning, which enables an unfertilized egg to yield stem cells as it grows. Researchers at the Oregon Health \& Science University and the Oregon National Primate Research Center in Beaverton have enhanced this approach to make it far more efficient and practical.

The team, led by Shoukhrat Mitalipov of the primate centre, evacuated all genetic material from the egg cell and replaced it with genetic material from a skin cell nucleus. The developing egg produced stem cells genetically identical to the donor. Those cells could theoretically be implanted in the donor, without any risk of rejection, and could subsequently mature to replace any tissue.

Such cloning recalls the famous copying of Dolly the sheep in the late $1990 \mathrm{~s}$, but the goal here was not to reproduce an entire organism. Instead, the Oregon project sought a stem cell line for tackling injury, disease and inherited disorders - a defining goal of personalized therapy.

While the mechanics of somatic cell nuclear transfer are straightforward and well established, it poses some daunting obstacles. Those begin with paying healthy women thousands of dollars to participate in the invasive process of harvesting their oocytes. Almost invariably, these egg cells stop developing before any stem cells appear, necessitating expensive, time-consuming attempts to obtain just a few viable samples.

This cumbersome, unpredictable method was eclipsed by the advent of induced pluripotent stem cells (iPSCs) in 2006. These are produced by using protein and viruses to alter sample

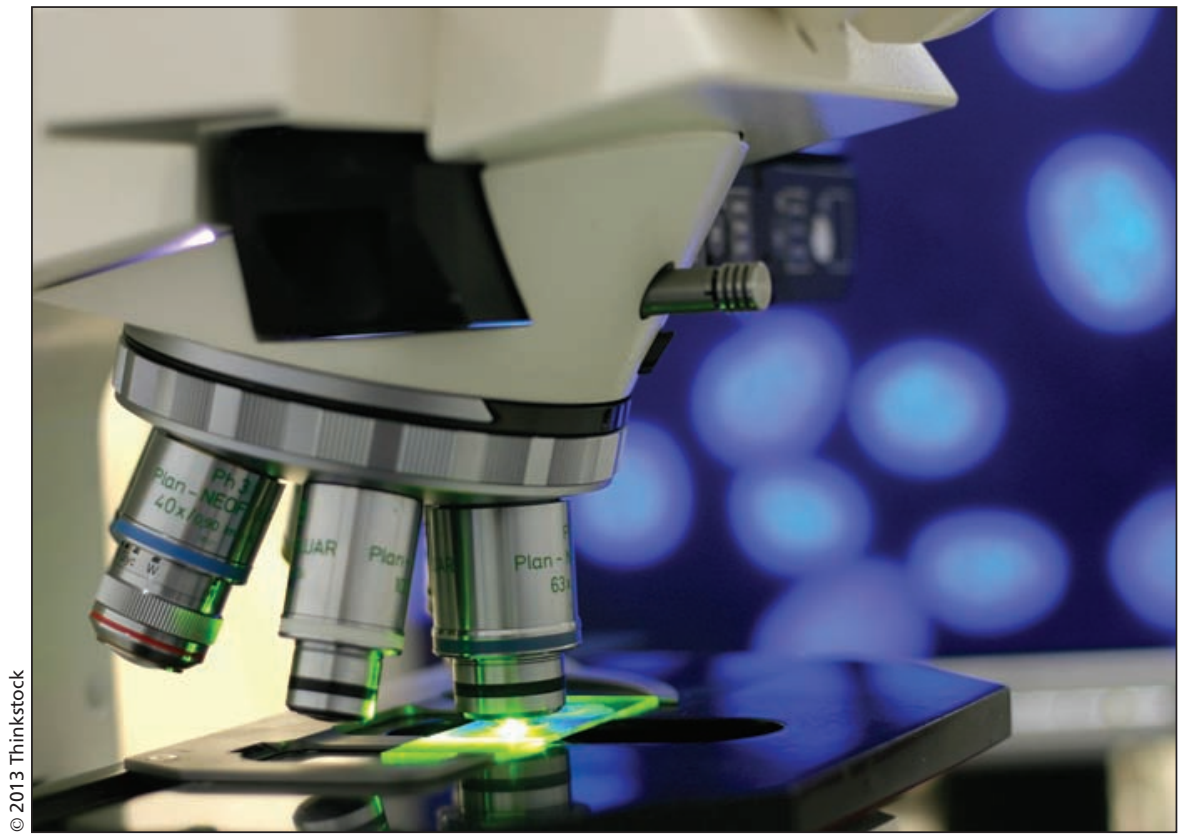

Somatic cell nuclear transfer is winning high praise for using fewer eggs to produce a far higher proportion of successful stem cell colonies.

cells, instead of transferring nuclear material or using oocytes. Ethical, economical and efficient, iPSCs won over most of the scientific community. This strategy is not without its own problems, however, such as inadvertently triggering cancer genes.

Mitalipov and his colleagues soldiered on with somatic cell nuclear transfer. It is now winning high praise for using fewer eggs to produce a far higher proportion of successful stem cell colonies. For some observers, though, it ranks as a technical accomplishment rather than a potential therapeutic breakthrough.

"This is an interesting experiment that's important to do, and it's important to compare those cells with the iPSC cells to see what their different properties are," says Janet Rossant, a leading stem cell investigator with Toronto's Hospital for Sick Children in Ontario. "But I don't think you're going to see it becoming a very widely used technique."

Zubin Master, an assistant professor with the Alden March Bioethics Institute at Albany Medical College in upstate New York, says such work suffers from an association with the social and cultural stigma around cloning. Raised and educated in Canada, he notes that this stigma was a factor in Canada's Assisted Human Reproduction Act, which became law in 2004. It made human cloning a criminal offence, expressly forbidding work like researchers are doing in Oregon. Canadian researchers may not want to do such work right now, but he notes that future progress could bring cloning back to the forefront.

"If ... we could bypass many of these hurdles, and make somatic cell nuclear transfer efficient and more ethically pleasing, then I could see people wanting to use this technology," he says.

Richard Gold, a law professor at McGill University, Montréal, Quebec, specializes in the intellectual property issues surrounding biotechnology. The threat of criminal prosecution could in principle discourage some Canadian researchers from venturing anywhere near somatic cell nuclear transfer or cloning, he argues, perhaps even driving 
away some enterprises dedicated to making therapeutic inroads.

He adds that there is no easy way of testing this negative proposition, nor are Canadian stem cell researchers voicing serious discomfort with the existing regime.

Jay Baltz, a senior scientist with the Ottawa Hospital Research Institute in
Ontario who currently chairs the Canadian Institutes of Health Research Stem Cell Oversight Committee, reports that this body simply does not encounter requests to do prohibited research. He concludes that the exotic prospects of cloning cannot compete with the more immediate, practical possibilities offered by stem cell technology.
"In order to use it medically, you need both to understand the basic biology of it, but also to be able to scale it up and make it practical to use," he says. "Most of the research proposals we see coming through are biotechnology." Tim Lougheed, Ottawa, Ont.

CMAJ 2013. DOI:10.1503/cmaj.109-4522 